\title{
The oldest record of the bivalve Dosinisca Dall and its implications
}

\author{
V D Borkar ${ }^{1}$ and Kantimati G KulKarni ${ }^{2, *}$ \\ ${ }^{1}$ P.G. Department of Geology, Fergusson College, Savitribai Phule Pune University, F. C. Road, Pune \\ 411004 , India. \\ ${ }^{2}$ Agharkar Research Institute, Savitribai Phule Pune University, G.G. Agarkar Road, Pune 411 004, India. \\ *Corresponding author.e-mail: kgkulkarni@aripune.org
}

MS received 10 July 2018; revised 14 September 2018; accepted 19 September 2018; published online 6 April 2019

Certain species of Dosinia occurring in the Miocene of Kachchh and the Pliocene of Balochistan in reality belong to the subgenus Dosinisca (Veneridae, Dosiniinae). This subgenus was hitherto known from the Quaternary of the Western Pacific Zoogeographic Province. The present study reveals that the first occurrence of Dosinisca is in the Khari Nadi Formation (Aquitanian) of Kachchh, India. The faunal affinity of the Kachchh Basin with the Alpine-European region through the Tethys fauna until Oligocene came to an end in the Lower Miocene due to the uplifting of the Himalayas. Later, during Lower Miocene, faunal migration took place between Kachchh and the Barrow Island off the northwestern coast of Australia, through the East Indies and Timor Island. After Dosinisca thrived in the Indian Subcontinent during Lower Miocene, the receding of marine waters endangered its very existence in this part of the globe. It somehow survived in Balochistan during Pliocene due to an episode of marine transgression. However, it must have migrated eastwards to the East Indies to be eventually established in the Western Pacific Zoogeographic Province.

Keywords. Dosinisca; Miocene of Kachchh; Himalayan upheaval; migration; Western Pacific Zoogeographic Province.

\section{Introduction}

Vredenburg $(1925,1928)$ gave a remarkable account of the fossil molluscs from the Oligocene, Miocene and Pliocene rock formations exposed in the Kachchh and Kathiawar regions of India as well as the Sindh and Balochistan states of Pakistan. The molluscan fauna described by him included four forms of the bivalve genus Dosinia Scopoli. They are (i) D. pseudoargus (d'Archiac and Haime), (ii) D. pseudoargus (d'Archiac and Haime) subsp. gedrosiana Vredenburg, (iii) D. subpenicillata Vredenburg and (iv) D. peralta Vredenburg.
While revising the fossil molluscs from the Miocene rock formations of Kachchh (Borkar et al. 2004, 2012, 2014, 2016; Kulkarni et al. 2009, 2010), the present authors had an opportunity to examine the type specimens of Dosinia described by Vredenburg, housed in the Central Fossil Repository of the Geological Survey of India (GSI), Kolkata. Furthermore, a few fossil specimens, closely comparable to those described by Vredenburg as Dosinia, were collected lately from the Miocene rocks of Kachchh by one of us (VDB). It was noticed that neither the type specimens referred to by Vredenburg nor the specimens 
collected from Kachchh belong to Dosinia (sensu stricto). It was then ascertained that one of the species belongs to the subgenus Asa Basterot, whereas the remaining species belong to the subgenus Dosinisca Dall.

So far, the occurrence of Dosinisca is known to be restricted to the Holocene of Japan, New Zealand and Australia (Dall 1902; Marwick 1927; Cox et al. 1969) and Pleistocene of Japan (Otuka 1929; Ichikawa 1988). Therefore, its presence in the Miocene and Pliocene rocks of the western and northwestern parts of the Indian subcontinent leads us to certain inferences pertaining to the place of its origin and its subsequent migration to faraway places in the east. Emerging findings are enunciated in the present communication. Some preliminary remarks about it were made earlier (Borkar et al. 2016).

The lithostratigraphic classification of the Miocene succession (table 1) proposed by Biswas (1992) is being followed by the present authors. The fossil molluscs were collected for the present study from the Miocene sections of the Abdassa Subdivision of the Kachchh district (figure 1). The lithocolumns of the studied sections are represented in figures 2 and 3.

Repository: The type specimens designated herein under the acronym MACS G are preserved in the Fossil Repository of the Agharkar Research Institute, Pune, India.

\section{Geological set-up}

The development of the Palaeogene and Neogene rocks in Peninsular India is the best in the Kachchh region. The Miocene epoch is represented here by sedimentary rocks having a thickness of about $700 \mathrm{~m}$, which are divided into two formations by Biswas (1992) (table 1). The older of the two is designated as the Khari Nadi Formation, while the younger as the Chhasra Formation. The Khari Nadi Formation rests on the Maniyara Fort Formation (Oligocene) with a paraconformity and consists mainly of variegated siltstones with a few intercalations of limestones rich in fossils. A fuller development is found in the tract between Jangadia and Haripar, where the lower one-third (ca. $22 \mathrm{~m}$ ) consists of variegated siltstones, which are rich in arthropod burrows, yet almost devoid of body fossils except a few impressions of nuculids and corbulids. The upper two-thirds (ca. $43 \mathrm{~m}$ ) contain siltstones alternating with unfossiliferous sandstone and fossiliferous limestone intercalations. This thickness is not developed at any other place. However, a Turritella bed occurs at the top of the Khari Nadi Formation, and is noticed in many localities including Buta, Haripar, Ramwada, Wagot, Charopadi and Khirsara. The Khari Nadi Formation is conformably overlain by the Chhasra Formation, which is subdivided into two members: a lower Claystone Member and an upper Siltstone Member. The Claystone Member

Table 1. Lithostratigraphic classification of the Miocene sediments of Kachchh (after Biswas (1992), pertinent part to the present communiqué).

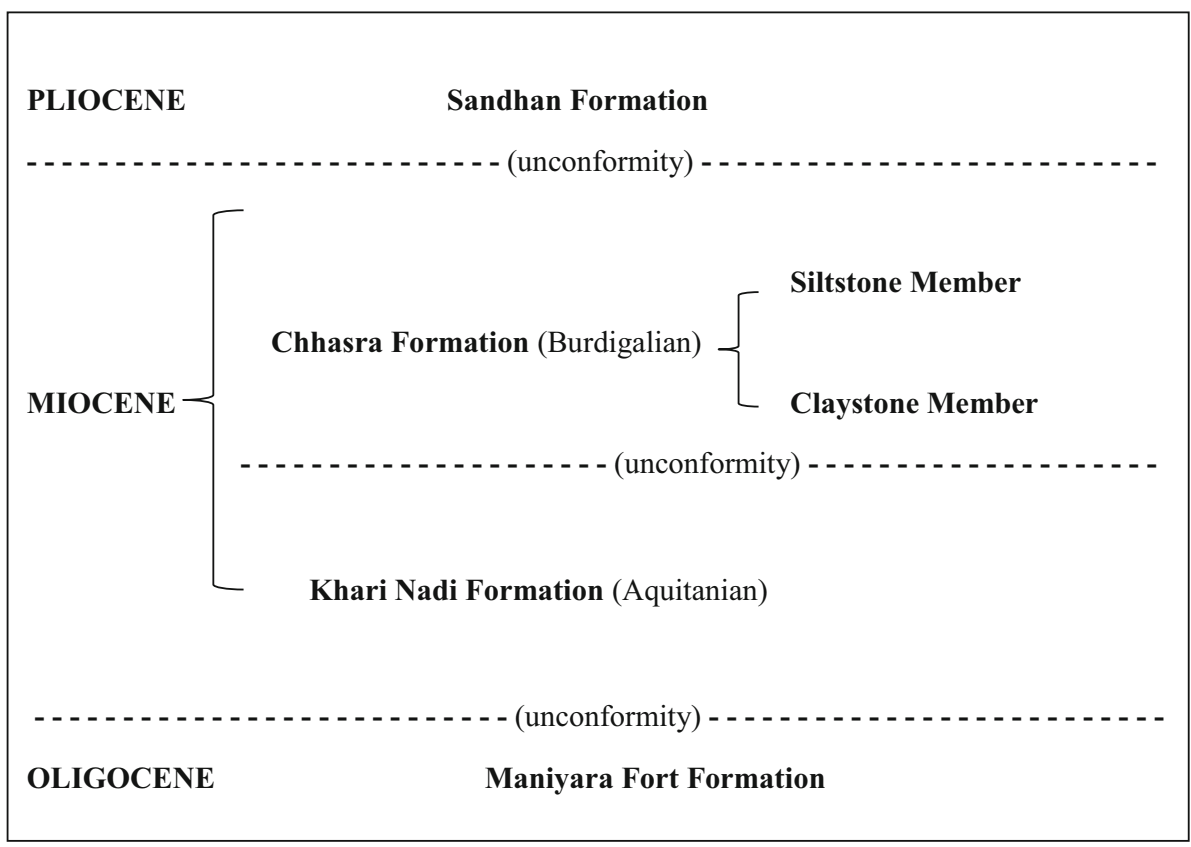




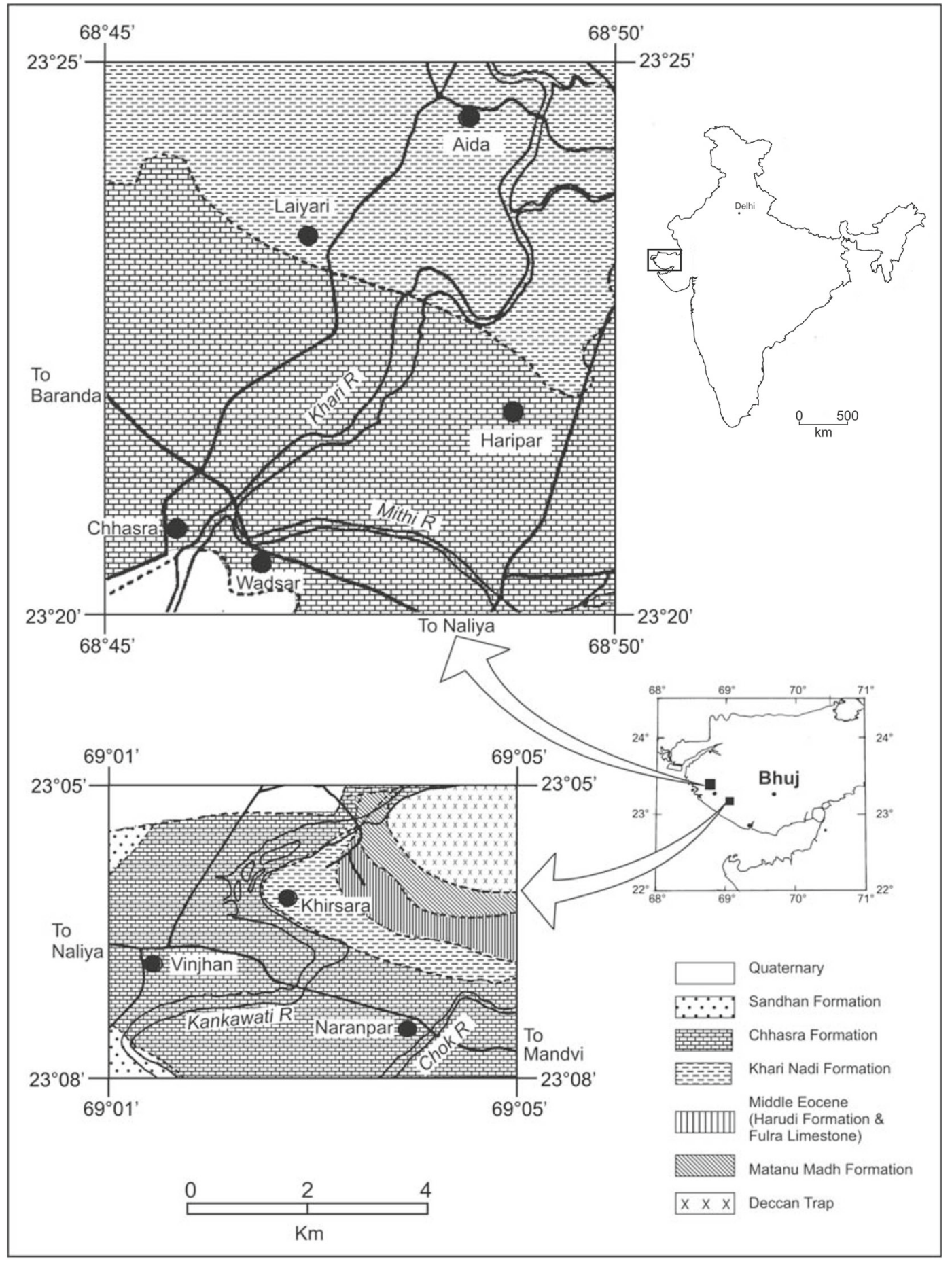

Figure 1. Geological map of parts of the Kachchh region, Gujarat state, India; slightly modified after Biswas an Deshpande (1970). Formational boundaries are approximate.

is punctuated by shell limestones, often rich in echinoids and molluscs. The Siltstone Member consists mainly of unfossiliferous silts containing a few thin sandstone intercalations and only two thin limestone intercalations. The Miocene sequence is followed by the sandstones of the Sandhan Formation with a distinct unconformity. On the basis of foraminfera, Raju (1974) has assigned an Aquitanian age to the Khari Nadi Formation, while a Burdigalian age for the Chhasra Formation.

The present authors have revised the molluscan fauna (Borkar et al. 2004, 2012, 2014, Kulkarni et al. 2009, 2010) and have given a checklist of 


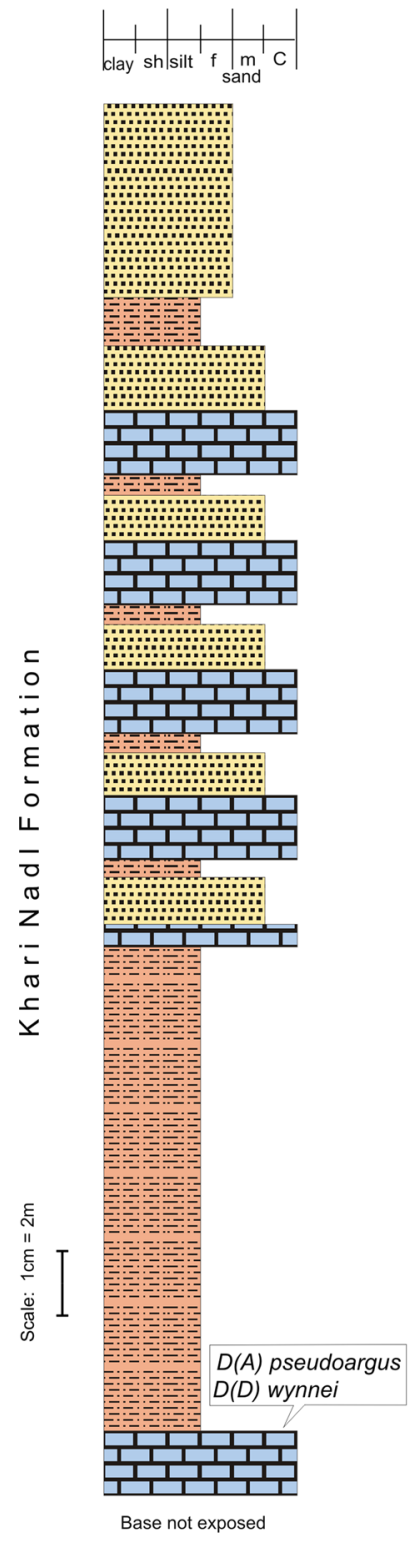

(a)

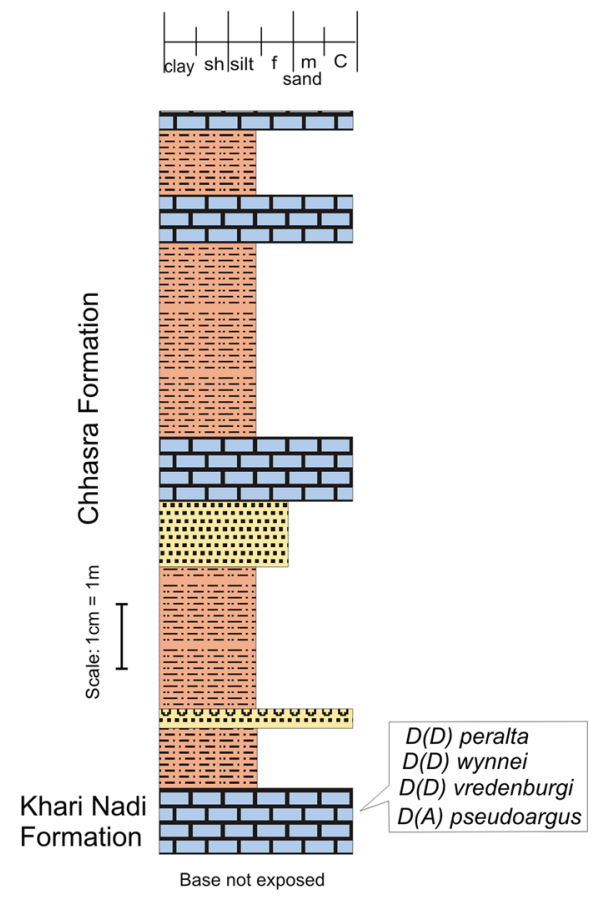

(b)

Figure 2. Sections from where the fossil specimens were collected. (a) Khari Nadi Formation exposed NE of Aida village. (b) Claystone Member, Chhasra Formation exposed NW of Haripar village.

123 species (47 bivalves and 79 gastropods) (Borkar et al. 2016). The fauna is mostly endemic; however, certain species typical of a Lower Miocene age predominate the assemblage. They include Periglypta aglaure, $P$. granosa, Chlamys $(C$.) senatoria, Placuna (Indoplacuna) sindiensis, Lucina (L.) orbicularis, Conus (Lithoconus) ineditus, Semicassis (S.) pila, Lyria (Harpeola) jugosa, Gyrineum bituberculare and Strombus (S.) sedanensis.

It may be mentioned here that Ostrea $(O)$ latimarginata, $O(O)$ angulata, $P$. (I.) sindiensis, Nemocardium (Discors) triforme, Zaria angulata and some other turritellids, Xenophora terpestrai,
Globularia $(G)$ carlei and Clathrus gajensis occur in large numbers.

On the basis of the relationship of this fauna with that of Sindh, Kathiawar, Kerala and Sri Lanka, it was inferred that they constitute a palaeozoogeographic province which Borkar et al. (2016) have designated as the Kachchh Burdigalian Palaeozoogeographic Province.

\section{Systematic description}

Order: Veneroida H. Adams and A. Adams, 1856

Superfamily: Veneracea Rafinesque, 1815 


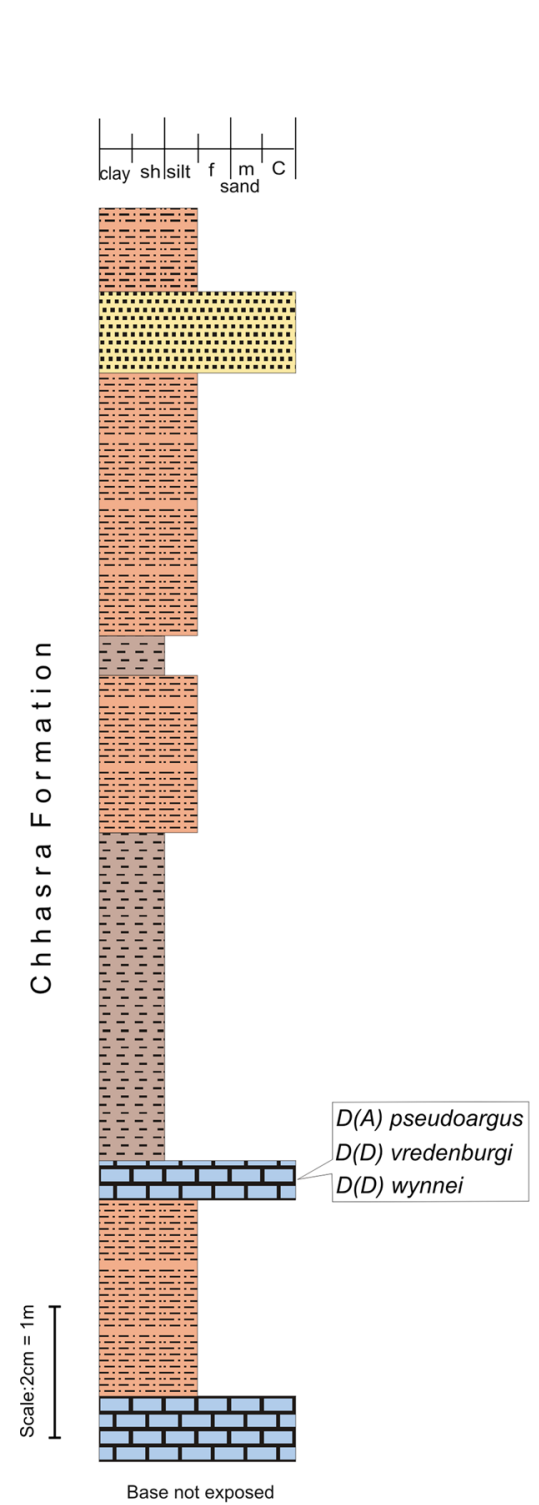

(a)

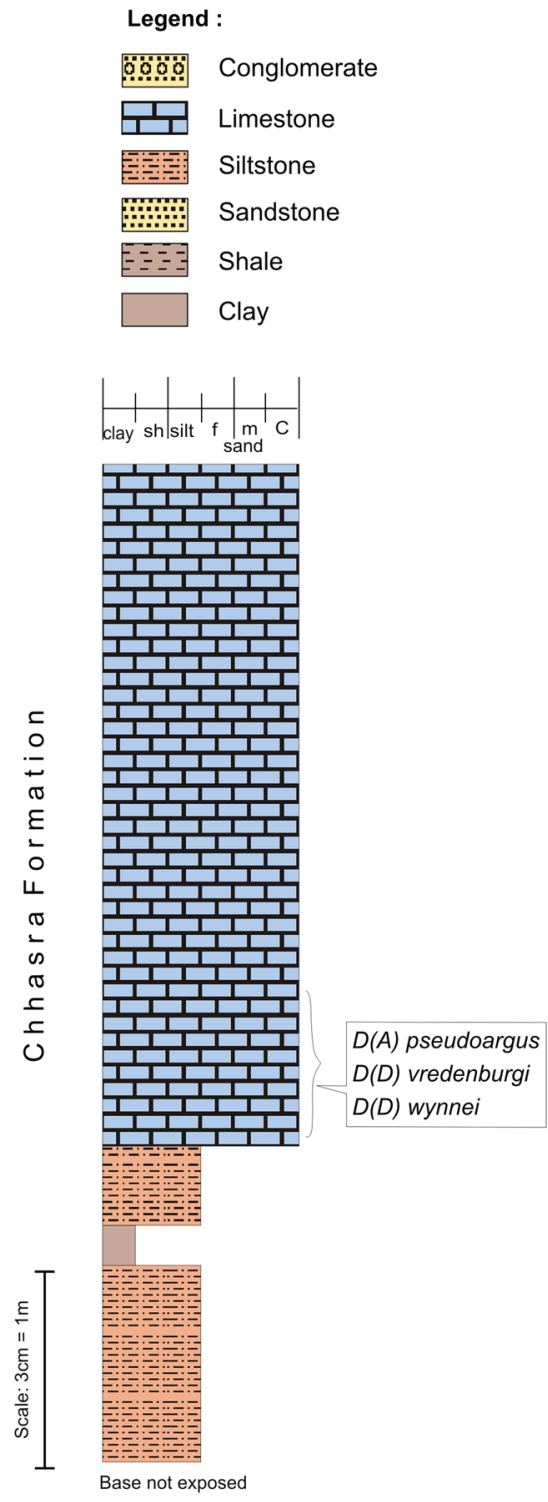

(b)

Figure 3. Sections from where the specimens were collected. (a) Claystone Member, Chhasra Formation exposed $1.5 \mathrm{~km}$ NNE of Chhasra village, Khari River section. (b) Claystone Member, Chhasra Formation exposed in the Kankavati River, south of Vinjhan-Manjal causeway.

Family: Veneridae Rafinesque, 1815

Subfamily: Dosiniinae, Deshayes, 1853

Genus: Dosinia Scopoli, 1777

Typespecies: Chama dosin Adanson, 1757

\subsection{Subgenus: Asa Basterot, 1825}

Typespecies: Venus lincta Pulteney, 1799

\subsubsection{Dosinia (Asa) pseudoargus}

(d'Archiac and Haime 1853) comb. nov

(plate 1, figures a-e)

Lucina pseudoargus (sp. nov.) d'Archiac and Haime 1853: p. 239, plates 42, figures 2-4.
Dosinia pseudoargus (d'Archiac and Haime) Vredenburg 1928: p. 447.

Material: (i) Seven specimens collected by the authors from the Miocene rocks of Kachchh. (ii) Two specimens housed in the Central Fossil Repository, Geological Survey of India, Kolkata; described by Vredenburg (1928).

Type specimens: (i) Plesiotype No. 13,521; Central Fossil Repository, Curatorial Wing, Geological Survey of India, Kolkata. (ii) Plesiotype No. MACS G 4944 and Paratype No. MACS G 4945; Repository 


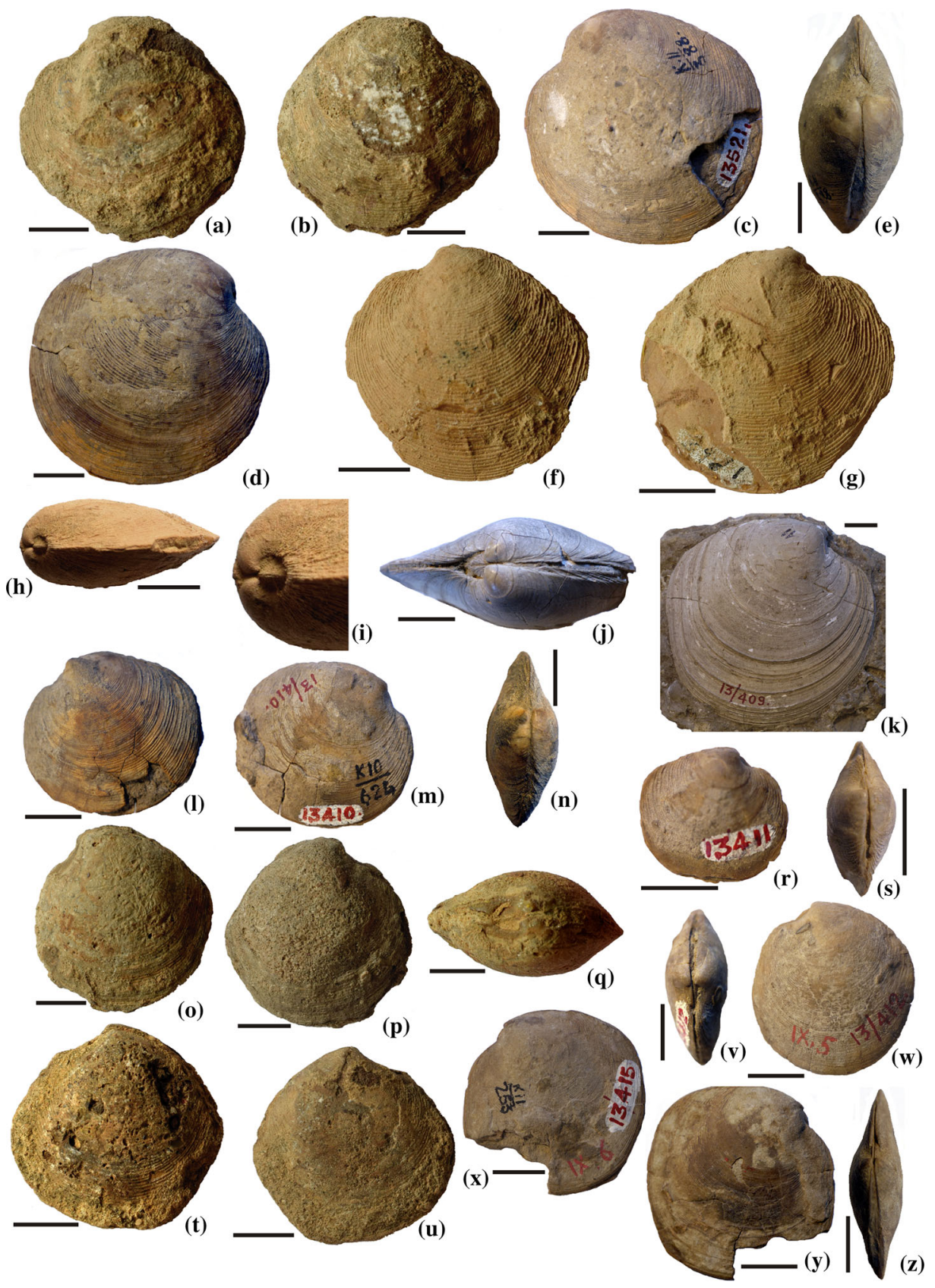

Plate 1. (a-e) Dosinia (Asa) pseudoargus (d'Archiac and Haime 1853) comb. nov. Scale bar = 10 mm. (a) Plesiotype No. MACS G. 4944-LV external view. (b) Plesiotype No. MACS G. 4944-RV external view. (c) Plesiotype GSI No. 13,521-LV external view. (d) Plesiotype GSI No. 13,521-RV external view. (e) Plesiotype GSI No. 13,521-dorsal view showing distinct short lunule and narrow escutcheon. (f-k) Dosinia (Dosinisca) vredenburgi sp. nov. (f) Plesiotype No. MACS G 5346-LV external view. (g) Plesiotype No. MACS G 5346-RV external view. (h) Plesiotype No. MACS G 5346. Antero-dorsal view showing the prosogyrate umbones and a short lunule. (i) Plesiotype No. MACS G 5346. Close-up of figure 2(h) showing the conspicuous pouting of a lunule. (j) Holotype GSI No. 13,308. Dorsal view showing the short, pouting lunule and long, narrow escutcheon. (k) Paratype GSI No. 13,409. RV external view exhibiting fine, concentric, lamellose ribs with acute crests. Also note straight posterior margins. (1-n) Dosinia (Dosinisca) subpenicillata (Vredenburg). (1) Holotype GSI No. 13,410. LV external view. (m) Holotype GSI No. 13,410. RV external view. (n) Holotype GSI No. 13,410. Dorsal view. (o-s) Dosinia (Dosinisca) wynnei sp. nov. (o) Plesiotype No. MACS G 5347. LV external view. (p) Plesiotype No. MACS G 5347. RV external view. (q) Plesiotype No. MACS G 5347. Dorsal view. Obvious greater inflation as compared to the other species. Also note pouting lunule and escutcheon. (r) Holotype GSI No. 13,411. RV external view. (s) Holotype GSI No. 13,411. Dorsal view. Note greater tumidity than GSI No. 13,410. (t-w) Dosinia (Dosinisca) peralta (Vredenburg). (t) Plesiotype No. MACS G 4946. LV external view. (u) Plesiotype No. MACS G 4946. RV external view. (v) Holotype GSI No. 13,412. Dorsal view. (w) Holotype GSI No. 13,412. LV external view. (x) GSI No. 13,415. LV external view. (y) GSI No. 13,415. RV external view. (z) GSI No. 13,415. Dorsal view. Note distinctly less inflated shell. 
of the Palaeobiology section, Agharkar Research Institute, Pune.

\section{Dimensions:}

\begin{tabular}{lccccc}
\hline $\begin{array}{l}\text { Specimen } \\
\text { no. }\end{array}$ & $\begin{array}{c}\mathrm{L} \\
(\mathrm{mm})\end{array}$ & $\begin{array}{c}\mathrm{H} \\
(\mathrm{mm})\end{array}$ & $\begin{array}{c}\mathrm{I} \\
(\mathrm{mm})\end{array}$ & $L / I$ & $H / I$ \\
\hline $\begin{array}{l}\text { GSI 13,521 (a) } \\
\text { BV }\end{array}$ & 48.6 & 47.5 & 22.5 & 2.16 & 2.11 \\
GSI 13,521 (b) & 53.0 & 51.1 & 23.1 & 2.29 & 2.21 \\
BV & & & & & \\
MACS G 4944 & 37.5 & 36.4 & 17.9 & 2.09 & 2.03 \\
$\quad$ (= ARI: & & & & & \\
D/5) BV & & & & & \\
MACS G 4945 & 43.4 & 41.5 & - & - & - \\
$\quad$ (=ARI: & & & & & \\
D/16)LV & & & & & \\
ARI: D/2 BV & - & - & 16.3 & - & - \\
ARI: D/4 BV & 40.5 & 39.0 & 17.8 & 2.27 & 2.19 \\
ARI: D/6 BV & 33.8 & - & 16.8 & 2.01 & - \\
ARI: D/11 BV & 42.3 & - & - & - & - \\
ARI: D/14 RV & - & - & - & - & - \\
\hline
\end{tabular}

Note: L: length, H: height, I: inflation.

Description: The shells are medium sized with an orbicular form and moderate inflation. Umbones are small and prosogyrate. Lunule is short, while escutcheon is long, narrow with well-developed nymphae; bordered by lamellose ribs. Distinctly even curvature of the anterior, ventral, posterior and postero-dorsal margins impart the orbicular outline to its shell. The external surface of the valves is ornamented with fine, concentric lamellose ribs with acute crests, with the inclination of the lamellae being away from umbones.

Remarks: A comparison of the specimens collected from Kachchh with the two plesiotypes of Dosinia pseudoargus, maintained under one registration number (Vredenburg 1928, p. 447; type specimen No. 13,521, Central Fossil Repository, Curatorial Wing, GSI, Kolkata) revealed that the Kachchh specimens agree in all essential respects with Vredenburg's types; especially with respect to the orbicular shape, lamellose concentric ribs, a short lunule and a long, narrow escutcheon with distinct nymphae.

Vredenburg had described this form as a species of the genus Dosinia Scopoli. However, an escutcheon is absent in Dosinia (s.s.) (Cox et al. 1969, p. N679). Moreover, though the ornamentation consisting of concentric ribs is diagnostic of Dosinia, it is never lamellose. Hence, the presence of an escutcheon and lamellose nature of the concentric ribs observed in the specimens under consideration warranted the rectification of the subgeneric identification of this form. A narrow escutcheon bordered by the lamellose sculpture and a deep lunule are the diagnostic features of the subgenus Asa Basterot (Cox et al. 1969, p. N679). Therefore, the present authors have described it under Asa.

Occurrence in Kachchh: (i) A shell limestone bed at the top of the lower one-third of the Khari Nadi Formation, $0.5 \mathrm{~km}$ NE of Aida. (ii) The Turritella bed towards the top of the Khari Nadi Formation, on the left bank of the Khari River, $2.0 \mathrm{~km}$ west of Haripar. (iii) A fossiliferous limestone intercalation in the Claystone Member of the Chhasra Formation, SSE of Chhasra village. (iv) A fossiliferous limestone intercalation in the Claystone Member of the Chhasra Formation, south of Khirsara village.

Distribution: The Khari Nadi and Chhasra formations of Kachchh, Ashapura Claystone Member of Kathiawar. Also, Gaj Beds of Sindh (Pakistan).

\subsection{Subgenus: Dosinisca Dall, 1902}

Type species: Atremis alata Reeve, 1859

\subsubsection{Dosinia (Dosinisca) vredenburgi sp. nov} (plate 1, figures $\mathrm{f}-\mathrm{k}$ )

Dosinia pseudoargus (d'Archiac and Haime) var. gedrosiana var. nov. 1928: Vredenburg, p. 448, plate 28 , figures 2,4 .

Diagnosis: Dosinisca with a distinct pouting within the lunule, while rather subdued within the escutcheon. Posterior margin almost straight with a slight sigmoidal course.

Material: (i) Four specimens collected by the authors from the Miocene rocks of Kachchh. (ii) Two specimens from the Lower Mekran Series of Balochistan, Pakistan; housed in the Central Fossil Repository, Curatorial Wing, Geological Survey of India, Kolkata; described by Vredenburg (1928).

Type specimens: (i) Holotype No. 13,408; Central Fossil Repository, Curatorial Wing, Geological Survey of India, Kolkata. (ii) Plesiotype No. MACS G 5346; Repository of the Palaeobiology section, Agharkar Research Institute, Pune.

Etymology: Specific epithet is in honour of Ernest Vredenburg. 
Dimensions:

\begin{tabular}{lccccl}
\hline Specimen no. & $\begin{array}{c}\mathrm{L} \\
(\mathrm{mm})\end{array}$ & $\begin{array}{c}\mathrm{H} \\
(\mathrm{mm})\end{array}$ & $\begin{array}{c}\mathrm{I} \\
(\mathrm{mm})\end{array}$ & $L / I$ & $H / I$ \\
\hline GSI 13,408 BV & 56.6 & 54.8 & 21.6 & 2.62 & 2.53 \\
GSI 13,409 RV & 64.5 & 63.8 & - & - & - \\
MACS G 5346 (= & 34.8 & 32.5 & 13.6 & 2.56 & 2.39 \\
ARI: D/15) BV & & & & & \\
ARI: D/3 BV & - & 37.8 & 15.7 & - & 2.41 \\
ARI: D/9 BV & 44.3 & 41.2 & 17.2 & 2.57 & 2.40 \\
ARI: D/10 & 46.8 & 43.1 & 19.5 & 2.40 & 2.21 \\
\hline
\end{tabular}

Note: L: length, H: height, I: inflation.

Description: The shells are medium sized with an orbicular form and moderate inflation. Umbones are prosogyrate. Lunule is short, while the escutcheon is long, narrow with well-developed nymphae. A small portion of the valves, close to their margins, is curved outward within the lunule and escutcheon, giving rise to pouting. The pouting is distinct within the lunule, while rather subdued within the escutcheon. The even curvature of the anterior, ventral, and postero-dorsal margins contributes to the orbicular shape of the shell; however, the posterior margin is almost straight showing a slightly sigmoidal course. The external surface of the valves is ornamented with fine, concentric lamellose ribs with acute crests. Lamellae are inclined away from the umbones. A few intermittent concentric ribs are stronger than the average.

Remarks: When compared with the holotypes of Dosinia pseudoargus var. gedrosiana of Vredenburg (1928, p. 448; type specimen No. 13,408 and 13,409, Central Fossil Repository, Curatorial Wing, GSI, Kolkata) from the Lower Mekran Series, the specimens from Kachchh were found to agree in all essential respects including the conspicuous pouting within lunule, subdued pouting within escutcheon, an exactly identical sculpture and the straight posterior margin which tends to be slightly sigmoidal.

Besides identifying this form under Dosinia, Vredenburg had also described it to be a subspecies of Dosina pseudoargus. It would now mean that this form is a subspecies of Asa pseudoargus. However, the presence of the pouting within the lunule and escutcheon would prohibit us from identifying this species under Asa. Therefore, its specific identity with Asa pseudoargus (d'Archiac and Haime) is erroneous and no more tenable. Considering this form as its subspecies is obviously out of question.

Since Dall (1902) had instituted the subgenus Dosinisca for the forms showing the pouting within the lunule and escutcheon, this form is identified here as a species of Dosinisca. The present species is named after Vredenburg.

Occurrence in Kachchh: (i) The Turritella Bed towards the top of the Khari Nadi Formation, on the left bank of the Khari River, $2.0 \mathrm{~km}$ west of Haripar. (ii) A fossiliferous limestone intercalation in the Claystone Member of the Chhasra Formation, SSE of Chhasra village. (iii) A fossiliferous limestone intercalation in the Claystone Member of the Chhasra Formation, south of Khirsara village.

Distribution: The Khari Nadi and Chhasra formations of Kachchh. Also, the Lower Mekran Series of Balochistan.

\subsubsection{Dosinia (Dosinisca) subpenicillata (Vredenburg) (plate 1, figures 1-n)}

Dosinia subpenicillata sp. nov., 1928: Vredenburg, p. 448, pars, plate 29, figure 7 (Holotype No. 13,410); non plate 29, figures 8, 9 (Holotype No. $13,411)$.

Material: One specimen from the Lower Mekran Series of Balochistan (Pakistan), housed in the Central Fossil Repository, Curatorial Wing, Geological Survey of India, Kolkata; described by Vredenburg (1928).

Type specimens: Holotype No. 13,410, Central Fossil Repository, Curatorial Wing, Geological Survey of India, Kolkata.

\section{Dimensions:}

\begin{tabular}{lccccc}
\hline $\begin{array}{l}\text { Specimen } \\
\text { no. }\end{array}$ & $\begin{array}{c}\text { Length } \\
(\mathrm{mm})\end{array}$ & $\begin{array}{c}\text { Height } \\
(\mathrm{mm})\end{array}$ & $\begin{array}{c}\text { Inflation } \\
(\mathrm{mm})\end{array}$ & $L / I$ & $H / I$ \\
\hline GSI & 29.5 & 32.20 & 12.1 & 2.44 & 2.66
\end{tabular}

$13,410 \mathrm{BV}$

Remarks: While describing this form as a new species of Dosinia, Vredenburg (1928) had given illustrations of two specimens, bearing type Nos. 13,410 and 13,411, from the Lower Mekran Series of Balochistan, Pakistan. However, these two 
specimens exhibit the presence of an escutcheon, lamellose concentric ribs and pouting within the lunule and escutcheon; they need to be identified as the species of the subgenus Dosinisca.

However, there are remarkable differences in these two specimens. They may resemble each other rather perfectly as regards their outline, but a closer examination revealed that specimen No. 13,410 is distinctly bigger in length and height, but equally less inflated, than the specimen No. 13,411. Therefore, the two specimens cannot be regarded as conspecific. Specimen No. 13,410 is retained here under the specific epithet subpenicillata as proposed by Vredenburg. The other holotype (Nos. 13,411), along with the three specimens collected recently, is identified as a new species (vide infra).

Distribution: Lower Mekran Series of Balochistan (Pakistan).

3.2.3 Dosinia (Dosinisca) wynnei sp. nov (plate 1, figure $\left.\mathrm{O}^{-} \mathrm{S}\right)$

Dosinia subpenicillata sp. nov., 1928: Vredenburg, p. 448, pars plate 29, figures 8, 9 (Holotype No. 13,411); non plate 29, figure 7 (Holotype No. $13,410)$.

Diagnosis: Dosinisca with remarkable inflation, which is nearly half of both length and height. The shape is orbicular tending to be oblong.

Material: (i) Three specimens collected by the authors from the Miocene rocks of Kachchh. (ii) One specimen from the Lower Mekran Series of Balochistan, housed in the Central Fossil Repository, Curatorial Wing, Geological Survey of India, Kolkata; described by Vredenburg (1928).

Type specimens: (i) Holotype No. 13,411; Central Fossil Repository, Curatorial Wing, Geological Survey of India, Kolkata. (ii) Plesiotype No. MACS G 5347; Repository of the Palaeobiology section, Agharkar Research Institute, Pune.

Etymology: In honour of Arthur Beevor Wynne.
Dimensions:

\begin{tabular}{lccccl}
\hline $\begin{array}{l}\text { Specimen } \\
\text { no. }\end{array}$ & $\begin{array}{c}\mathrm{L} \\
(\mathrm{mm})\end{array}$ & $\begin{array}{c}\mathrm{H} \\
(\mathrm{mm})\end{array}$ & $\begin{array}{c}\mathrm{I} \\
(\mathrm{mm})\end{array}$ & $L / I$ & $H / I$ \\
\hline GSI 13,411 BV & 19.2 & 17.6 & 8.7 & 2.20 & 2.02 \\
$\begin{array}{l}\text { MACS G 5347 } \\
\quad(=\text { ARI: D/12) BV }\end{array}$ & 36.6 & 35.7 & 18.5 & 1.98 & 1.92 \\
ARI: D/17 BV & 28.3 & 27.9 & 13.7 & 2.07 & 2.03 \\
ARI:D/19 BV & 32.8 & - & 16.6 & 1.98 & - \\
\hline
\end{tabular}

Note: L: length, H: height, I: inflation.

Description: The shells are medium to small sized. The shape is orbicular tending to be oblong. Inflation is fairly more than that in other species of Dosinisca, associated in field. Lunule is short, while the escutcheon is long, narrow with welldeveloped nymphae. A small portion of valves within the lunule and escutcheon, close to their margins, is curved outward; giving rise to pouting. The even curvature of the anterior and ventral margins contributes to the orbicular shape of the shell, but the postero-dorsal margin is almost straight giving it a slightly oblong appearance. The external surface of the valves is ornamented with fine, concentric lamellose ribs with acute crests. Lamellae are inclined away from the umbones. All concentric ribs are almost of uniform prominence.

Remarks: The three specimens collected by the present authors from the Miocene rock formations of Kachchh were compared with the type specimen No. 13,411, identified as Dosinia subpenicillata by Vredenburg (1928, p. 448, plate 29, figures 8, 9; Central Fossil Repository, Curatorial Wing, Geological Survey of India, Kolkata) from the Lower Mekran Series of Balochistan (Pakistan). They agree in all essential respects including dimensions, orbicular shape tending to be oblong and moderate inflation.

Among all the dosiniids being reported herein, this form is distinctly more tumid. It has already been discussed why the two holotypes (Nos. 13,410 and 13,411) placed by Vredenburg (1928) under Dosinia subpenicillata are not conspecific. Since specimen No. 13,410 is retained under the specific epithet subpenicillata, it is necessary that the other one (No. 13,411), along with three specimens collected by the present authors from the Miocene of Kachchh, need to be described as a new species. This species is named after Wynne. 
Occurrence in Kachchh: (i) The Turritella Bed towards the top of the Khari Nadi Formation, on the left bank of the Khari River, $2.0 \mathrm{~km}$ west of Haripar. (ii) A fossiliferous limestone intercalation in the Claystone Member of the Chhasra Formation, SSE of Chhasra village. (iii) A fossiliferous limestone intercalation in the Claystone Member of the Chhasra Formation, south of Khirsara village.

Distribution: The Khari Nadi and Chhasra formations of Kachchh. Also, the Lower Mekran Series of Balochistan, Pakistan.

\subsubsection{Dosinia (Dosinisca) peralta (Vredenburg) (plate 1, figures $\mathrm{t}-\mathrm{z}$ )}

Dosinia peralta sp. nov., 1928: Vredenburg, p. 449, plate 29, figures 1-6.

Material: (i) Two specimens collected by the authors from the Miocene rocks of Kachchh. (ii) Four specimens from the Lower Mekran Series of Balochistan housed in the Central Fossil Repository, Geological Survey of India, Kolkata; described by Vredenburg.

Type specimens: (i) Holotype No. 13,412; Central Fossil Repository, Curatorial Wing, Geological Survey of India, Kolkata. (ii) Plesiotype No. MACS G 4946 and 4947; Repository of the Palaeobiology section, Agharkar Research Institute, Pune.

Dimensions:

\begin{tabular}{lccccc}
\hline $\begin{array}{l}\text { Specimen } \\
\text { no. }\end{array}$ & $\begin{array}{c}\mathrm{L} \\
(\mathrm{mm})\end{array}$ & $\begin{array}{c}\mathrm{H} \\
(\mathrm{mm})\end{array}$ & $\begin{array}{c}\mathrm{I} \\
(\mathrm{mm})\end{array}$ & $L / I$ & $H / I$ \\
\hline GSI 13,412 BV & 29.8 & 31.2 & 12.1 & 2.46 & 2.58 \\
GSI 13,413 BV & 27.6 & 28.2 & 11.1 & 2.48 & 2.54 \\
GSI 13,414 LV & 32.6 & 33.7 & - & - & - \\
GSI 13,415 BV & 34.2 & 35.0 & 10 & 3.42 & 3.5 \\
MACS G 4946 & 32.2 & 33.3 & 13.7 & 2.35 & 2.43 \\
$\quad$ (= ARI: & & & & & \\
$\quad$ D/20) BV & & & & & \\
MACS G 4947 & - & 32.0 & 12.7 & - & 2.52 \\
$\quad$ (= ARI: D/8) & & & & & \\
BV & & & & & \\
\end{tabular}

Note: L: length, H: height, I: inflation.

Description: The shells are medium sized with an orbicular form and moderate inflation. Umbones are small and prosogyrate. Lunule is short and deep; while the escutcheon is long and narrow with well-developed nymphae, bordered by lamellose ribs. A small portion of valves within the lunule and the escutcheon is curved outward, giving rise to pouting. The external surface of the valves is ornamented by fine, concentric lamellose ribs with acute crests. Lamellae are inclined away from the umbones. Height is slightly more than the length.

One of the two Kachchh specimens (Plesiotype No. 4947) is an entire shell with conjoined valves, but its valves are slightly dislocated. Also, a fragment of the antero-dorsal portion is lost. Hence it was not possible to measure its length. Similarly, Vredenburg's type specimen No. 13,414 is a single valve. It was not possible to measure its thickness accurately.

Remarks: Like the earlier four forms, the present species also shows the presence of an escutcheon, pouting within lunule and escutcheon, and ornamentation consisting of lamellose ribs. Hence this species is also to be transferred to the subgenus Dosinisca.

Vredenburg had included four type specimens in his Dosinia peralta, but a careful examination revealed that specimen No. 13,415 is slightly bigger than the remaining three (plate 1 , figures $\mathrm{x}$ and $\mathrm{y}$ ). Also, it shows much less inflation (figure 4) (plate 1, figure z). Probably, it belongs to a separate species. However, identifying it as a new species is deferred for want of more material.

A comparison of the specimens from the Miocene of Kachchh in the authors' collection with type specimens of Vredenburg (1928, p. 449. plate 29, figures 1-5; Holotype Nos. 13,412, 13,413 and 13,414) Central Fossil Repository, Curatorial Wing, GSI, Kolkata) from the Lower Mekran Series of Balochistan, Pakistan revealed that they agree in all essential respects with the Balochistan specimens.

Occurrence in Kachchh: (1) The Turritella Bed towards the top of the Khari Nadi Formation, on the left bank of the Khari River, $2.0 \mathrm{~km}$ west of Haripar.

Distribution: The Khari Nadi Formation of Kachchh. Also, the Lower Mekran Series of Balochistan (Pakistan).

\section{Discussion}

Dosinisca is an extant subgenus and as of today, it occurs in the North and South Pacific. Dall (1902) and Marwick (1927) had recorded their presence in Australia, New Zealand and Japan (figure 5). 


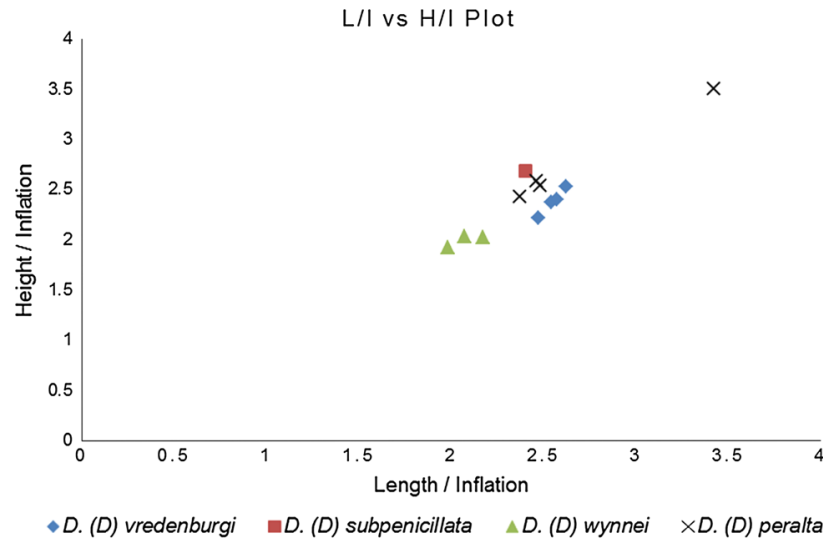

Figure 4. Bivariate plot of length:Inflation vs. height: Inflation of the four species of Dosinisca described herein. Note the marked difference in the dimensions of GSI specimen No. 13,415, presently identified as $D$. (D.) peralta.

Later, its presence from the Pleistocene of Japan came to light when $D$. (Dosinisca) pubescens was recorded by Otuka (1929) and Ichikawa (1988).

The present communiqué has shown that certain specimens occurring in the Miocene and Pliocene of the western and northwestern parts of the Indian Subcontinent, including those described by Vredenburg (1928) as Dosinia, actually belong to the subgenus Dosinisca. This certainly asks for a revision of known spatial and temporal distribution of this subgenus (figure 5).

As revealed by the present investigation, three species viz., Dosinia (Dosinisca) vredenburgi, D. (D.) wynnei and $D$. (D.) peralta, occur in the Khari Nadi Formation of the Aquitanian age. The occurrence of Dosinia (Dosinisca) wynnei in the shell limestone bed at the top of the lower onethird of the Khari Nadi Formation, $0.5 \mathrm{~km}$ NE of Aida village, is the first global appearance for this subgenus.

In order to evince its subsequent occurrences in the Pleistocene of Japan as well as in the present day marine waters of Japan, Australia and New Zealand; it is to be recalled that McNamara and Kendrick (1994) identified a few common elements between the Miocene faunas of Kachchh and the Barrow Island off the northwest coast of Australia. They found that the echinoid genera Breynia and Tripneustes procured by them from the Miocene rocks of Barrow Island were recorded from the Miocene rocks of Kachchh (Duncan and Sladen 1883). They further observed that these two genera are common elements of the modern Australian fauna as well. They further commented that the present day echinoids of the North Coast of
Australia differ from those of the South Coast, but at the same time have an affinity with the echinoids occurring in the Miocene of the East Indies.

A revision of the fossil molluscs from the Miocene rocks of Kachchh by the present authors (Borkar et al. 2004, 2012, 2014, 2016; Kulkarni et al. 2009, 2010; Harzhauser et al. 2009) has strengthened the affinities between Miocene molluscan assemblages of Barrow Island and Kachchh by identifying 10 related elements (table 2). The present authors have also attempted to find evidence of affinity between the Miocene fauna of the Barrow Island and fauna of Miocene rock formations of the East Indies (table 3). In view of such affinities, it was postulated by Borkar et al. (2016, p. 103, figure 3) that the migration of marine fauna effectively took place during Burdigalian between the Kachchh Burdigalian Palaeozoogeographic Province of Borkar et al. (2016) and the Austral-Indo-Pacific Tertiary Province of Crespin (1950), through the East Indies and Timor.

It is suggested here that Dosinisca evolved from some unidentified venerid stock during Aquitanian in the Kachchh epicontinental sea. In this regard, a close similarity between Dosinia (Asa) pseudoargus and Dosinia (Dosinisca) vredenburgi appears to be significant. The similarity is so striking that Vredenburg (1928) had considered $D$. (D.) vredenburgi as the subspecies of $D$. (A.) pseudoargus under the name Dosinia pseudoargus var. gedrosiana. This remarkable similarity hints that Dosinisca might have evolved from $A s a$.

As the Tethys ceased to exist, and the marine waters receded from the Kachchh Basin (Pascoe 1964), the existence of Dosinisca in this part of the globe was endangered. It is observed that it somehow could survive in Balochistan during a marine transgression in Pliocene. And then Dosinisca became extinct in this part of the globe. Thereafter, it is recorded from the Pleistocene of Japan and the modern fauna of Japan, Australia and New Zealand. Therefore, it appears that in an attempt to overcome the threat to its survival, the subgenus must have migrated to the East Indies during Burdigalian itself. It might have settled there first for some time and then migrated farther to Japan, Australia and New Zealand through Timor. There is a likelihood that various species, that must have evolved in due course, are fossilised in the post-Burdigalian rock formations of the East Indies and Timor. 


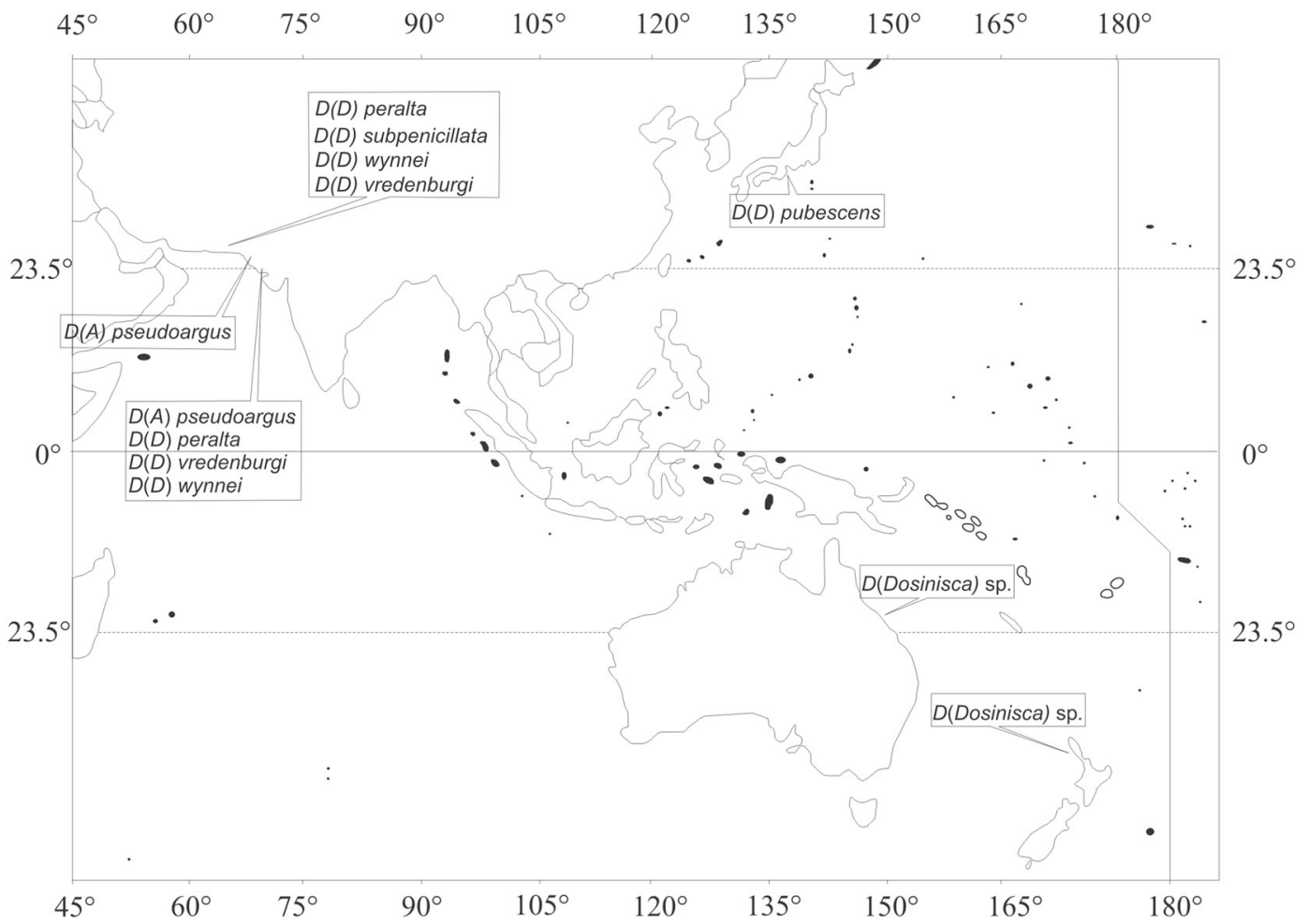

Figure 5. Map showing the distribution of the subgenus Dosinisca.

Table 2. Species present in the Miocene of Barrow Island having affinity with the Kachchh Burdigalian Province.

Name of the species from the Miocene of the Barrow Island

1. Acrosterigma sp.

2. Periglypta sp.

3. Varicospira sp. [= Rimella sp. aff. R. cancellata of McNamara and Kendrick]

\section{Tripneustes pregratilla}

Related form the Kachchh Burdigalian Province

1. Acrosterigma (Vasticardium) sp. from the Chhasra Formation of Kachchh, and

2. Acrosterigma quilonensis [=Cardium quilonense of Dey] from the Quilon Formation of Kerala

3. P. aglaure, from the Khari Nadi and Chhasra Formations of Kachchh, Gaj Beds of Sindh; and

4. Periglypta granosa, from the Khari Nadi and Chhasra Formations of Kachchh, Ashapura Member of Kathiawar, Gaj Beds of Sindh and Kudremalai Formation of Sri Lanka

5. Varicospira narica from the Chhasra Formation of Kachchh

6. Varicospira subrimosa from the Khari Nadi Formation of Kachchh and the Quilon Formation of Kerala

7. T. antiquus from the Miocene of Kachchh

8. T. provaia from the Miocene of Kachchh
The exact duration of the existence of Dosinisca at different sojourns on its long voyage is yet to be understood. Why it could not survive anywhere else in its course from Kachchh to its final destination is a moot question, at least today. It is hoped that sooner or later, fossils of Dosinisca will be procured from the post-Miocene rock formations in the East Indies and Timor by the palaeontological community, to mitigate the lacunae in our knowledge. 
Table 3. Species present in the Miocene of Barrow Island having affinity with the Miocene of the East Indies.

\begin{tabular}{|c|c|}
\hline Name of the species & Related form from the Miocene of the East Indies \\
\hline 1. Periglypta sp. & Periglypta granosa, from the Miocene of Java \\
\hline 2. Tellina sp. & Tellina retifera from the Miocene of Java \\
\hline 3. Xenophora sp. & Related to Xenophora pallidula from the Miocene of Java \\
\hline $\begin{array}{l}\text { 4. Strombus (Tricornis) aff. S.(T.) } \\
\text { maximus }\end{array}$ & Strombus (Tricornis) maximus occurs in the Miocene of Java \\
\hline 5. Strombus (Lentigo) sp. & Strombus (Lentigo) preoccupatus from the Miocene of Borneo \\
\hline 6. Ampullina butleri & Ampullina bandongensis from the Miocene of Java \\
\hline 7. Melongena sp. & Melongena gigas from the Miocene of Java \\
\hline
\end{tabular}

\section{Acknowledgements}

Our sincere thanks are due to the Director, Curatorial Division, Geological Survey of India, Kolkata for making the type specimens available for the study and permitting to include their photographs. The authors would like to place on record that the late Mr G W Kendrick of the Western Australia Museum, Perth had confirmed the taxonomic identifications.

\section{References}

Biswas and Deshpande S V 1970 Geological and tectonic of Kutch; Bull Oil Nat. Gas Comm. 7 115-116.

Biswas S K 1992 Tertiary stratigraphy of Kutch; J. Palaeontol. Soc. India 37 1-29.

Borkar V D, Kulkarni K G and Bhattacharjee S 2004 Molluscan fauna of the Miocene sediments of Kachchh, Gujarat, India - Part 1. Oysters; Geophytology 34 1-7.

Borkar V D, Kulkarni, K G and Bhattacharjee Kapoor S 2012 Molluscan fauna of the Miocene sediments of Kachchh, Gujarat, India - Part 5. Reporting of Ostrea gajensis Vredenburg from the Chhasra Formation; Gondwana Geol. Mag. 27 93-96.

Borkar V D, Kulkarni K G and Bhattacharjee Kapoor S 2014 Molluscan fauna of the Miocene sediments of Kachchh, Gujarat, India - Part 4. Indarca, a new anadaroid subgenus; J. Geol. Soc. India 83 290-294.

Borkar V D, Kulkarni K G and Bhattacharjee Kapoor S 2016 An overview of fossil molluscs from the Miocene sedimentary rocks of Kachchh; Geol. Soc. India Spec. Publ. 6 89-105.

Cox L R, Newell N D, Boyd D W, Branson C R, Chavan A, Coogan A H, Dechaseaux C, Fleming C A, Haas F, Hertlein C, Kauffman E G, Keen A M, Larocque A, Mcalester A L, Moore R C, Nuttall C, Perkings B F, Puri H S, Smith L A, Soot-Ryen T, Stenzel H B, Trueman E R, Turner R D and Weir J 1969 In: Treatise on invertebrate paleontology (ed.) Moore R C, The Geological Society of America and University of Kansas Press, Part N, 1-2, Mollusca 6 N, 952p.
Crespin I 1950 Australian Teritary microfauna and theri relationships to assemblages elsewhere in the Pacific region; J. Paleontol. 24 421-429.

Dall W H 1902 Synopsis of the family veneridae and of the North American species; Proc. US Natl. Mus. 26 $335-412$.

d'Archiac V and Haime J 1853 Description des animaux fossils du groupe Nummulitique de l'Inde Gide et J Baudry, Paris, 373p.

Duncan M and Sladen W 1883 The fossil echinoidea of Kutch and Kathyawar; Palaeontol. Indica 14 1-91.

Harzhauser M, Reuter M, Piller W E, Berning B, Kroh A and Mandic O 2009 Oligocene and early Miocene gastropods from Kutch (NW India) document an early biogeographic switch from Western Tethys to Indo-Pacific; Palaeont. Z 83 333-372.

Ichikawa T 1988 Catalogue of type and illustrated specimens in the department of historical geology and palaeontology of the university museum, university of Tokyo: Part III; Supplement (1), Material Reports No. 15.

Kulkarni K G, Borkar V D and Bhattacharjee Kapoor S 2009 Molluscan fauna of the Miocene sediments of Kachchh, Gujarat, India - Part 2. Bivalve subgenus Indoplacuna; Cainozoic Res. 6 71-81.

Kulkarni K G, Borkar V D and Bhattacharjee Kapoor S 2010 Molluscan fauna of the Miocene sediments of Kachchh, Gujarat, India - Part 3. Gastropods; J. Earth Syst. Sci. 119 307-342.

Marwick J 1927 The veneridae of New Zealand; Trans. New Zealand Inst. 57 567-635.

McNamara K J and Kendrick G W 1994 Cenozoic mollusca and echinoids of Barrow Island, Western Australia; Records of the Western Australian Museum Supplement No. 51; Western Australian Museum, Perth, pp. 1-50.

Otuka Y 1929 A stratigraphical study of the Oiso block and its adjacent area. Part 1; J. Geol. Soc. Tokyo 36 435-456 (in Japanese).

Pascoe E H 1964 A manual of the geology of India and Burma 3; 3rd edn, Geological Survey of India Misc. Publication, Kolkata, pp. 1345-2130.

Raju D S N 1974 Observation of the Eocene, Oligocene and Miocene foraminiferal biostratigraphy of Kutch, Western India; Centre of Advanced Studies in Geology, Panjab University, Chandigarh 10 136-155. 
Vredenburg E 1925 Description of Mollusca from the Post-Eocene Tertiary formation of north western India: Cephalopoda, Opisthobranchiata, Siphonostomata Gastropoda; Mem. Geol. Surv. India 50351.
Vredenburg E 1928 Description of Mollusca from the Post-Eocene Tertiary formation of north western India: Gastropoda (in part) and Lamellibranchiata; Mem. Geol. Surv. India 50 351-506.

Corresponding editor: Pratul K SARASWATI 